\title{
ETNOFARMAKOLOGI DAN INVENTARISASI TUMBUHAN OBAT DI KECAMATAN KAPUAS HILIR KABUPATEN KAPUAS KALIMANTAN TENGAH
}

\author{
Ethnopharmacology And Medicinal Plant Inventory In Kapuas Hilir District, Kapuas \\ District, Central Kalimantan
}

\section{Nurul Qamariah"* \\ Rezqi handayani' \\ Opi Indriani ${ }^{2}$}

IDosen Pengajar Program Studi D-III Farmasi, Fakultas Ilmu Kesehatan, Universitas Muhammadiyah Palangkaraya

2Mahasiswa Program Studi D-III Farmasi, Fakultas IImu Kesehatan, Universitas Muhammadiyah Palangkaraya

*email:enqiyu9@gmail.com

\section{Kata Kunci:}

Etnofarmakologi

Inventarisasi

Kapuas Hilir

Tumbuhan berkhasiat obat

\section{Keywords:}

Ethnopharmacology

Inventory

Kapuas Hilir

Medicinal Plants.

\begin{abstract}
Etnofarmakologi adalah ilmu yang mempelajari tentang kegunaan tumbuhan yang memiliki efek farmakologi untuk pengobatan dan pemeliharaan kesehatan dalam suatu suku bangsa. Studi etnofarmakologi dilakukan di Kecamatan Kapuas Hilir Kabupaten Kapuas. Hal ini dikarenakan masyarakat Kecamatan Kapuas Hilir Kabupaten Kapuas masih memanfaatkan tumbuhan berkhasiat obat untuk menyembuhkan penyakit yang khasiatnya diketahui secara turun-temurun. Penelitian ini bertujuan untuk mendapatkan data berupa jenis tumbuhan, bagian yang digunakan, cara pengolahan dan untuk mengetahui apakah khasiat empiris tumbuhan berkhasiat obat yang digunakan didukung oleh data hasil penelitian. Penelitian ini dilakukan menggunakan metode penelitian kualitatif dengan rancangan deskriptif, teknik pada pengumpulan data menggunakan observasi, wawancara, dan dokumentasi. Hasil Penelitian didapatkan 22 jenis tumbuhan berkhasiat obat yang digunakan untuk mengobati berbagai penyakit yaitu Rabangun, Kumis Kucing, Keji Beling, Sawangkak, Karamunting Bulu, Kastela, Sirsak, Mangkudu, Katatuak, Gusar, Kalanduyung, Tabuluh, Insulin, Galinggang, Urang Iru, Uru Balanda, Henda Baputi, Uru Samue, Panawar Gantung, Sukun, Pahakung, dan Kalamenyu. Bagian tumbuhan yang digunakan yaitu kulit batang, rimpang, bunga, herba, batang, akar dan yang paling banyak digunakan adalah bagian daun. Cara pengolahannya yaitu direndam air hangat, dibakar, dibuat kapsul, dikonsumsi langsung, ditumbuk dan yang paling sering adalah diolah dengan cara direbus. Khasiat empiris dari tumbuhan berkhasiat obat yang digunakan sebagian besar masih belum didukung oleh data hasil penelitian.
\end{abstract}

\begin{abstract}
Ethnopharmacology is the study of the use of plants that have pharmacological effects for the treatment and health care of an ethnic group. The ethnopharmacological study was conducted in Kapuas Hilir District, Kapuas Regency. This is because the people of Kapuas Hilir District, Kapuas Regency still use medicinal plants to cure diseases whose properties have been known from generation to generation. This study aims to obtain data in the form of plant species, parts used, processing methods and to find out whether the empirical properties of the medicinal plants used are supported by research data. This research was conducted using qualitative research methods with descriptive design, techniques in data collection using observation, interviews, and documentation. The results showed 22 types of medicinal plants used to treat various diseases, namely Rabangun, Cat's Whiskers, Keji Beling, Sawangkak, Karamunting Bulu, Kastela, Soursop, Mangkudu, Katatuak, Gusar, Kalanduyung, Tabuluh, Insulin, Galinggang, Urang Iru, Uru. Balanda, Henda Baputi, Uru Samue, Panawar Gantung, Breadfruit, Pahakung, and Kalamenyu. The plant parts used are the bark, rhizomes, flowers, herbs, stems, roots and the most widely used are the leaves. The processing method is soaked in warm water, burned, made capsules, consumed directly, pounded and most often is processed by boiling. Most of the empirical properties of medicinal plants used are still not supported by research data.
\end{abstract}

(C) year The Authors. Published by Institute for Research and Community Services Universitas Muhammadiyah Palangkaraya. This is Open Access article under the CC-BY-SA License (http://creativecommons.org/licenses/bysa/4.0/). DOI: https://doi.org//0.33084/jsm.vxix.xxx. 


\section{PENDAHULUAN}

Etnofarmakologi merupakan ilmu yang mempelajari tentang kegunaan tumbuhan yang memiliki efek farmakologi yang dalam hubungannya dengan pengobatan dan pemeliharaaan kesehatan suatu suku bangsa. Etnofarmakologi atau pengobatan tradisional mampu memberikan informasi yang sangat berguna sebagai langkah awal penelitian serta dapat mengumpulkan informasi pengobatan dari etnis tertentu (Sintha, 20I2). Pemanfaatan tumbuhan yang memiliki efek farmakologi untuk pengobatan dan pencegahan penyakit yang terkait dengan etnik (kelompok masyarakat) tertentu dikaji dalam ilmu etnofarmakologi (Mirdeilami et al., 20I I).

Kalimantan Tengah merupakan salah satu provinsi di pulau Kalimantan yang masyarakatnya hingga saat ini adalah Suku Dayak. Tumbuhan obat bukan merupakan hal yang asing bagi masyarakat Suku Dayak di Kalimantan Tengah. Tumbuhan saat ini menjadi salah satu pilihan bagi masyarakat Suku Dayak di Kalimantan Tengah dalam terapi pengobatan (Pitoyo \& Triwahyudi, 2017).

Suku Dayak yang ada di Kabupaten Kapuas hingga saat ini masih mempertahankantradisi dengan memanfaatkan tumbuhan disekitarnya untuk pengobatan, sehingga pengobatan tradisional masih menjadi solusi utama yang dipilih masyarakat suku Dayak dalam memelihara kesehatan. Kapuas Hilir merupakan salah satu kecamatan yang masyarakatnya masih memanfaatkan dan menggunakan tumbuhan sebagai salah satu obat tradisional untuk menyembuhkan penyakit. Pengetahuan lokal mengenai penggunaan tumbuhan berkhasiat obat yang ada di Kecamatan Kapuas Hilir masih belum terdokumentasi dengan baik. Pengetahuan lokal tersebut biasanya hanya disampaikan secara lisan dari generasi ke generasi. Seiring waktu semakin berkurangnya minat generasi muda untuk melestarikan pengetahuan lokal tersebut maka akan menjadikan pengetahuan tersebut lambat laun akan punah.
Berdasarkan latar belakang di atas peneliti merasa perlu untuk melestarikan pengetahuan lokal tersebut dengan melakukan pendataan dan dokumentasi mengenai khasiat empiris dari tumbuhan berkhasiat obat yang digunakan oleh masyarakat Kapuas Hilir Kabupaten Kapuas, sehingga pengetahuan lokal mengenai tumbuhan berkhasiat obat tersebut tidak hilang, dan peneliti juga merasa perlu untuk melakukan studi pustaka terhadap khasiat empiris dari tumbuhan tersebut sehingga dapat diketahui bahwa khasiat empiris tumbuhan yang selama ini digunakan oleh masyarakat Kahayan Hilir telah didukung dengan adanya data hasil penelitian yang berupa kajian ilmiah.

\section{METODOLOGI}

Penelitian ini menggunakan metode penelitian kualitatif dengan rancangan penelitian deskriptif. Dalam penelitian ini deskriptif yang digunakan yaitu dengan mendeskripsikan penggunaan Tumbuhaan Berkhasiat Obat di Kecamatan Kapuas Hilir Kabupaten Kapuas berupa bagian yang digunakan, khasiat empiris, cara pengolahan, aturan pakai, lama penggunaan, dan literatur sesuai khasiat empiris.

Alat yang digunakan dalam penelitian ini adalah kamera, alat perekam, kantong plastik, gunting, isolatif transparan, sasak, kertas koran, kertas label, kertas karton, penggaris, dan pedoman observasi dan pedoman wawancara yang sudah dipersiapkan terlebih dahulu. Observasi merupakan tahapan awal dari penelitian yang dilakukan di Kecamatan Kapuas Hilir Kabupaten Kapuas yaitu dengan mencari informasi tentang pengobat tradisional yang memanfaatkan tumbuhan berkhasiat obat di daerah tersebut.

Metode yang digunakan dalam pengumpulan data dilakukan dengan wawancara secara terstruktur yaitu dengan mewawancarai informan, kemudian pertanyaan tersebut satu persatu diperdalam untuk mencari informasi atau keterangan lebih lanjut 
(Sugiyono, 2010). Berdasarkan data hasil wawancara, peneliti memperoleh data tumbuhan berkhasiat obat yang digunakan oleh masyarakat Suku Dayak di Kecamatan Kapuas Hilir Kabupaten Kapuas.

Pembuatan herbarium kering dilakukan pada tumbuhan yang belum diketahui nama lainnya. Proses pembuatan herbarium kering terdiri dari empat tahap yaitu: pengumpulan sampel, pengeringan, pengawetan dan pembuatan herbarium (Steenis, 2005).

Determinasi dilakukan pada tumbuhan yang belum diketahui nama latinnya, dengan cara mengirim herbarium kering tumbuhan ke Lembaga IImu Pengetahuan Indonesia Pusat Penelitian Biologi untuk mengetahui jenis atau spesies dari tumbuhan berkhasiat obat yang diperlukan pada saat studi pustaka (Study Literatur) efek farmakologis yang dihasilkan.

Analisis data dilakukan sejak penelitian tersebut dilakukan, oleh karena itu data yang diperoleh dari lapangan segera disalin dalam bentuk tulisan dan kemudian dianalisis. Penarikan kesimpulan dilakukan dengan metode triangulasi data, yaitu peneliti menggunakan berbagai sumber data yang dapat digunakan selama riset atau penelitian dilakukan. Dari hasil triangulasi data tersebut akan didapatkan hubungan antara khasiat empiris dan penelitian ilmiah tentang tumbuhan berkhasiat obat asal Kecamatan Kapuas Hilir Kabupaten Kapuas sebagai obat tradisional.

\section{HASIL DAN PEMBAHASAN}

Berdasarkan hasil wawancara yang telah dilakukan dengan menggunakan pedoman wawancara, didapatkan hasil 22 jenis tumbuhan berkhasiat obat yang berasal dari Kecamatan Kapuas Hilir Kabupaten Kapuas. Tumbuhan yang telah diketahui nama latinnya selanjutnya akan dilakukan studi pustaka untuk melihat sejauh mana penelitian terkait dengan tumbuhan tersebut telah dilakukan, dan tumbuhan yang belum diketahui nama latinnya akan peneliti lakukan determinasi terlebih dahulu untuk mengetahui nama latinnya dengan mengirim ke Lembaga IImu Pengetahuan Indonesia (LIPI).Tumbuhan yang belum diketahui nama latinnya terdapat 3 (tiga) jenis yaitu tumbuhan dengan nama lokal Urang Iru, Pahakung dan Kalamenyu. Sampel tumbuhan diolah menjadi herbarium kering selanjutnya dikirim ke Lembaga IImu Pengetahuan Indonesia Pusat Penelitian Konservasi Tumbuhan dan Kebun Raya Bogor untuk dilakukan determinasi. Data hasil penelitian berupa nama tumbuhan, bagian yang digunakan, khasiat empiris, cara pengolahan, aturan pakai, lama penggunaan, serta data hasil studi pustaka dari tumbuhan berkhasiat obat di Kecamatan Kapuas Hilir Kabupaten Kapuas akan disajikan dalam bentuk tabel berikut: 
Tabel I. Tumbuhan didukung literatur sesuai empiris

\begin{tabular}{|c|c|c|c|c|c|c|}
\hline No & $\begin{array}{c}\text { Nama } \\
\begin{array}{c}\text { Tumbuhan } \\
\text { Obat }\end{array} \\
\end{array}$ & $\begin{array}{c}\text { Bagian } \\
\text { Digunakan }\end{array}$ & $\begin{array}{l}\text { Khasiat } \\
\text { Empiris }\end{array}$ & Cara Pengolahan & Aturan Pakai & $\begin{array}{c}\text { Literatur Sesuai } \\
\text { Khasiat } \\
\text { Empiris } \\
\end{array}$ \\
\hline $\mathrm{I}$. & 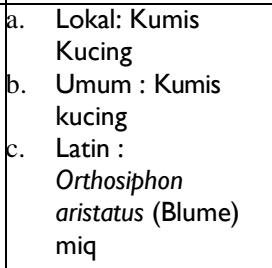 & $\begin{array}{l}\text { Akar dan } \\
\text { daun }\end{array}$ & $\begin{array}{l}\text { Mengobati } \\
\text { infeksi } \\
\text { saluran } \\
\text { kemih }\end{array}$ & $\begin{array}{l}\text { Akar dan daun } \\
\text { Kumis Kucing } \\
\text { direbus dengan air } \\
\text { hingga mendidih. }\end{array}$ & $\begin{array}{l}\text { Air rebusan akar dan } \\
\text { daun Kumis Kucing } \\
\text { diminum } 2 x \text { sehari I } \\
\text { gelas. }\end{array}$ & $\begin{array}{l}\text { (Reshi et al., 20I7) } \\
\text { Judul : Evaluation of } \\
\text { Antibacterial Potential of Leaf } \\
\text { And Leaf Derived Callus } \\
\text { Extracts of Orthosiphon } \\
\text { Aristatus (Blume) Miq. }\end{array}$ \\
\hline 2. & $\begin{array}{ll}\text { a. } & \text { Lokal : Keji } \\
& \text { Beling } \\
\text { b. } & \text { Umum : Keji } \\
& \text { Beling } \\
\text { c. } & \text { Latin : } \\
& \text { Strobilanthes } \\
& \text { crispa Bl. }\end{array}$ & $\begin{array}{l}\text { Daun dan } \\
\text { batang }\end{array}$ & $\begin{array}{l}\text { Mengobati } \\
\text { batu Ginjal }\end{array}$ & $\begin{array}{l}\text { Daun dan batang } \\
\text { Keji Beling direbus } \\
\text { dengan air hingga } \\
\text { mendidih. }\end{array}$ & $\begin{array}{l}\text { Air rebusan daun dan } \\
\text { batang Keji Beling } \\
\text { diminum } 2 x \text { sehari I } \\
\text { gelas. }\end{array}$ & $\begin{array}{l}\text { (Dharma et al., 20I4) } \\
\text { Judul : Pengaruh Ekstrak } \\
\text { Etanol Daun Kejibelin } \\
\text { (Strobilanthes crispa (L) } \\
\text { Blume) Terhadap Kelarutan } \\
\text { Kalsium dan Oksalat Sebagai } \\
\text { Komponen Batu Ginjal Pada } \\
\text { Urin Tikus Putih Jantan. }\end{array}$ \\
\hline 3. & $\begin{array}{ll}\text { a. } & \text { Lokal : Sirsak } \\
\text { b. } & \text { Umum : Sirsak } \\
\text { c. } & \text { Latin : Annona } \\
& \text { muricata .L. }\end{array}$ & Daun & $\begin{array}{l}\text { Menurunka } \\
\text { n tekanan } \\
\text { darah tinggi }\end{array}$ & $\begin{array}{l}\text { Daun Sirsak } \\
\text { direbus dengan air } \\
\text { hingga mendidih }\end{array}$ & $\begin{array}{l}\text { Air rebusan daun } \\
\text { Sirsak diminum } 3 x \\
\text { sehari I gelas }\end{array}$ & $\begin{array}{l}\text { (Sukandar et al, 20l4) } \\
\text { Judul : Uji Efek Penurunan } \\
\text { Tekanan Darah Ekstrak } \\
\text { Etanol Daun Sirsak (Annona } \\
\text { muricata L.) pada Tikus } \\
\text { Wistar Jantan. } \\
\text { (Sangging et al, 20l7) } \\
\text { Judul : Efektivitas Teh Daun } \\
\text { Sirsak (Annona muricata Linn) } \\
\text { terhadap Hipertensi. }\end{array}$ \\
\hline 4. & $\begin{array}{ll}\text { a. } & \text { Lokal : Katatuak } \\
\text { b. } & \text { Umum : } \\
& \text { Mondokaki } \\
\text { c. } & \text { Latin } \\
& \text { :Tabernaemontan a } \\
& \text { divaricata (L) }\end{array}$ & Kulit batang & $\begin{array}{l}\text { Mengobati } \\
\text { bisul di dalam } \\
\text { hidung }\end{array}$ & $\begin{array}{l}\text { Kulit batang } \\
\text { Katatuak ditumbuk } \\
\text { hingga mengeluarkan } \\
\text { air, dan peras airnya. }\end{array}$ & $\begin{array}{l}\text { Air perasan kulit batang } \\
\text { Katatuak, dioleskan Ix } \\
\text { sehari pada bagian } \\
\text { hidung yang terkena } \\
\text { bisul. }\end{array}$ & $\begin{array}{l}\text { (Baishya et al, 20l8) } \\
\text { Judul : Antimicrobial Potential } \\
\text { and In Vitro Cytotoxicity study } \\
\text { of Tabernaemontana divaricata } \\
\text { (L.) Stem Bark Extract Against } \\
\text { HEK } 293 \text { Cell Line. }\end{array}$ \\
\hline 5. & $\begin{array}{ll}\text { a. } & \text { Lokal : } \\
& \text { Kalanduyung } \\
\text { b. } & \text { Umum : Jati } \\
& \text { Belanda } \\
\text { c. } & \text { Latin : } \\
& \text { Guazuma } \\
& \text { ulmifolia } \\
& \text { Lamk. }\end{array}$ & Daun & $\begin{array}{l}\text { Mengobati } \\
\text { batuk }\end{array}$ & $\begin{array}{l}\text { Daun Kalanduyung } \\
\text { direbus dengan air } \\
\text { hingga mendidih . }\end{array}$ & $\begin{array}{l}\text { Air rebusan daun } \\
\text { Kalanduyung diminum } \\
3 x \text { sehari I gelas. }\end{array}$ & $\begin{array}{l}\text { (Trisia et al, 20l8) } \\
\text { Judul : Uji Aktivitas } \\
\text { Antibakteri Ekstrak Etanol } \\
\text { Daun Kalanduyung (Guazuma } \\
\text { ulmifolia Lamk.) Terhadap } \\
\text { Pertumbuhan Staphylococcus } \\
\text { aureus dengan Metode Difusi } \\
\text { Cakram (Kirby-Bauer). }\end{array}$ \\
\hline \multirow[t]{2}{*}{6.} & \multirow[t]{2}{*}{$\begin{array}{ll}\text { a. } & \text { Lokal : Insulin } \\
\text { b. } & \text { Umum : Insulin } \\
\text { c. } & \text { Latin : Tithonia } \\
& \text { diversifolia (hemsl) }\end{array}$} & \multirow[t]{2}{*}{$\begin{array}{l}\text { Batang, daun, } \\
\text { dan akar }\end{array}$} & \multirow[t]{2}{*}{$\begin{array}{l}\text { Menurunkan } \\
\text { kada gula } \\
\text { darah }\end{array}$} & $\begin{array}{l}\text { Daun Insulin } \\
\text { dikeringkan, } \\
\text { diserbukan, dan } \\
\text { dimasukan ke dalam } \\
\text { kapsul. }\end{array}$ & $\begin{array}{l}\text { Kapsul daun Insulin } \\
\text { diminum } 3 \times \text { sehari I } \\
\text { kapsul. }\end{array}$ & \multirow{2}{*}{$\begin{array}{l}\text { (Sari et al., 20I8) } \\
\text { Judul: Antihyperglycemic } \\
\text { Activity of Aqueous Extract } \\
\text { of Insulin Leaves (Tithonia } \\
\text { diversifolia) on Hyperglycemic } \\
\text { Rats (Rattus norvegicus). } \\
\text { (Sitanggang, 20I8) } \\
\text { Judul : Uji Efek Infusa Daun } \\
\text { Kembang Bulan (Tithonia } \\
\text { diversivolia (Hermsl.) A. Gray) } \\
\text { Terhadap Penurunan Kadar } \\
\text { Gula Darah Pada Tikus Putih } \\
\text { dengan Glibenklamid Sebagai } \\
\text { Pembanding. }\end{array}$} \\
\hline & & & & $\begin{array}{l}\text { Daun, batang, dan } \\
\text { akar Insulin direbus } \\
\text { dengan air hingga } \\
\text { mendidih. }\end{array}$ & $\begin{array}{l}\text { Air rebusan daun, } \\
\text { batang dan akar Insulin } \\
\text { dapat diminum kapan } \\
\text { saja. }\end{array}$ & \\
\hline \multirow[t]{2}{*}{7.} & \multirow[t]{2}{*}{ 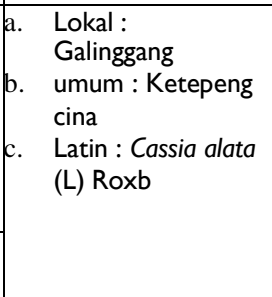 } & Daun & $\begin{array}{l}\text { Menurunka n } \\
\text { kadar } \\
\text { kolestrol }\end{array}$ & $\begin{array}{l}\text { Daun gelinggang } \\
\text { direbus dengan air } \\
\text { hingga mendidih, } 3 \\
\text { Lembar daun untuk } \\
\text { I gelas air. }\end{array}$ & $\begin{array}{l}\text { Air rebusan daun } \\
\text { Gelinggang diminum Ix } \\
\text { sehari I gelas. }\end{array}$ & $\begin{array}{l}\text { (Depita, 20l8) Judul: } \\
\text { Uji Aktivitas } \\
\text { Antihiperlipidemia Ekstrak } \\
\text { Etanol Daun Ketepeng Cina } \\
\text { (Cassia alata) Terhadap Tikus } \\
\text { Putih Jantan Galur Wistar Yang } \\
\text { Diinduksi Propiltiourasil }\end{array}$ \\
\hline & & Daun & $\begin{array}{l}\text { Mengobati } \\
\text { panu }\end{array}$ & $\begin{array}{l}\text { Daun Gelinggang } \\
\text { ditumbuk hingga }\end{array}$ & $\begin{array}{l}\text { Air perasaan daun } \\
\text { Gelinggang dioleskan }\end{array}$ & (Triana et al., 2017) \\
\hline
\end{tabular}


Nurul Qamariah, Rezqi Handayani, Opi Indriani. 202I. Ethnopharmacology And Medicinal Plant Inventory In Kapuas Hilir District, Kapuas District, Central Kalimantan

\begin{tabular}{|c|c|c|c|c|c|c|}
\hline & & & & $\begin{array}{l}\text { halus, dan peras } \\
\text { airnya. }\end{array}$ & $\begin{array}{l}\text { 1x sehari pada bagian } \\
\text { kulit yang terkena panu. }\end{array}$ & $\begin{array}{l}\text { Judul : Aktivitas Antijamur } \\
\text { ekstrak Daun Ketepeng Cina } \\
\text { (Cassia alata L.). }\end{array}$ \\
\hline \multirow[t]{2}{*}{8.} & \multirow{2}{*}{$\begin{array}{l}\text { a. Lokal : Uru } \\
\text { Balanda } \\
\text { b. Umum : Rumput } \\
\text { Paitan } \\
\text { c. Latin : Paspalum } \\
\text { conjugatum Berg. }\end{array}$} & \multirow[t]{2}{*}{ Daun } & $\begin{array}{l}\text { Mengobati } \\
\text { luka dalam }\end{array}$ & $\begin{array}{l}\text { Daun Uru Balanda } \\
\text { ditumbuk dan peras } \\
\text { airnya. }\end{array}$ & $\begin{array}{l}\text { Air perasan daun Uru } \\
\text { Belanda diminum } 2 x \\
\text { sehari. }\end{array}$ & \multirow{2}{*}{$\begin{array}{l}\text { (Muswanto, 20I9) Judul : Uji } \\
\text { Aktivitas Antibakteri Ekstrak } \\
\text { Etanol Daun Jukut Pahit } \\
\text { (Paspalum conjugatum) Asal } \\
\text { Desa Pongruan Kabupaten } \\
\text { Manggarai Timur Terhadap } \\
\text { Bakteri Staphylococcus aureus } \\
\text { Dan Kajian Senyawa Aktif. }\end{array}$} \\
\hline & & & $\begin{array}{l}\text { Mengobati } \\
\text { luka luar }\end{array}$ & $\begin{array}{l}\text { Daun Uru Balanda } \\
\text { ditumbuk hingga } \\
\text { halus. }\end{array}$ & $\begin{array}{l}\text { Daun Uru Belanda yang } \\
\text { sudah ditumbuk, } \\
\text { ditempelkan pada } \\
\text { bagian kulit yang luka, } \\
\text { dan biarkan hingga } \\
\text { mengering. }\end{array}$ & \\
\hline 9. & 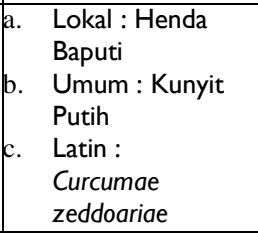 & Rimpang & $\begin{array}{l}\text { Mengobati } \\
\text { bisul }\end{array}$ & $\begin{array}{l}\text { Rimpang Henda } \\
\text { Baputi ditumbuk } \\
\text { hingga halus. }\end{array}$ & $\begin{array}{l}\text { Rimpang Henda Baputi } \\
\text { yang sudah ditumbuk, } \\
\text { dioleskan pada bisul } \\
\text { hingga mengering. }\end{array}$ & $\begin{array}{l}\text { (Lai et al., 2004) Judul } \\
\text { Antimicrobial Activity and } \\
\text { Cytotoxicity of the Essential Oil } \\
\text { of Curcuma zedoaria. }\end{array}$ \\
\hline 10. & $\begin{array}{l}\text { a. Lokal : Uru } \\
\text { Samue } \\
\text { b. Umum : Rumput } \\
\text { Samue, Lakum Air } \\
\text { c. Latin : Ludwigia } \\
\text { decurrens Walter. }\end{array}$ & Daun & $\begin{array}{l}\text { Mengobati } \\
\text { bisul }\end{array}$ & $\begin{array}{l}\text { Daun Uru Samue } \\
\text { ditumbuk hingga } \\
\text { halus. }\end{array}$ & $\begin{array}{l}\text { Daun Uru Samue yang } \\
\text { sudah ditumbuk, } \\
\text { dioleskan pada bisul } \\
\text { hingga mengering. }\end{array}$ & $\begin{array}{l}\text { (Oyedeji et al., 20II) } \\
\text { Judul : Antibacterial, } \\
\text { antifungal and phytochemical } \\
\text { analysis of crude extracts from } \\
\text { the leaves of Ludwigia } \\
\text { abyssinica A. Rich. And } \\
\text { Ludwigia decurrens Walter. }\end{array}$ \\
\hline II. & 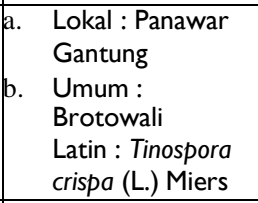 & Batang & $\begin{array}{l}\text { Meredakan } \\
\text { nyeri sakit } \\
\text { pingang }\end{array}$ & $\begin{array}{l}\text { Batang Panawar } \\
\text { Gantung direndam } \\
\text { dengan air hangat. }\end{array}$ & $\begin{array}{l}\text { Air rendaman batang } \\
\text { Panawar Gantung } \\
\text { diminum } 2 \text { x sehari I } \\
\text { gelas. }\end{array}$ & $\begin{array}{l}\text { (Septian et al., 20I6) Judul: } \\
\text { Uji Efek Analgetik Infusa } \\
\text { Batang Brotowali } \\
\text { (Tinospora crispa (L.) Miers) Pada } \\
\text { Mencit Putih Jantan Galur Swiss } \\
\text { (Mus musculus) }\end{array}$ \\
\hline 12. & 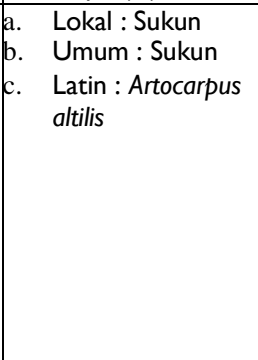 & Daun & $\begin{array}{l}\text { Menurunka } \mathrm{n} \\
\text { kolesterol }\end{array}$ & $\begin{array}{l}\text { Daun Sukun direbus } \\
\text { dengan air hingga } \\
\text { mendidih. }\end{array}$ & $\begin{array}{l}\text { Air rebusan daun Sukun } \\
\text { diminum } 2 x \text { sehari I } \\
\text { gelas. }\end{array}$ & 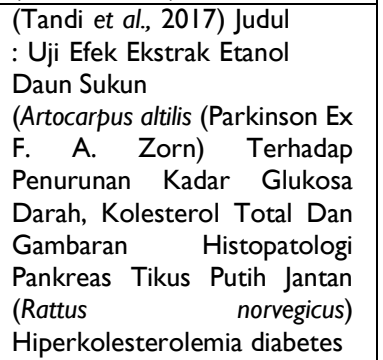 \\
\hline 13. & $\begin{array}{l}\text { a. Lokal : Pahakung } \\
\text { b. Umum : Kepala } \\
\text { Tupai } \\
\text { c. Latin : Drynaria } \\
\text { quercifolia (L) J. Sm. }\end{array}$ & $\begin{array}{l}\text { Daun, batang, } \\
\text { akar dan } \\
\text { rimpang }\end{array}$ & $\begin{array}{l}\text { Mengobati } \\
\text { kanker }\end{array}$ & $\begin{array}{l}\text { Daun, batang, akar, } \\
\text { dan rimpang } \\
\text { Pahakung dirajang, } \\
\text { dikeringkan, lalu } \\
\text { direbus dengan air } \\
\text { hingga mendidih. }\end{array}$ & $\begin{array}{l}\text { Air rebusan daun, } \\
\text { batang, akar dan } \\
\text { rimpang Pahakung } \\
\text { diminum } 3 \times \text { sehari I } \\
\text { gelas. }\end{array}$ & $\begin{array}{l}\text { (Prasanna et al., 2019) Judul : In } \\
\text { Vitro Evaluation Of Antidiabetic } \\
\text { And Cytotoxicity Potentials Of } \\
\text { The Rhizome Extract Of } \\
\text { Drynaria quercifolia (L.) J. Smith }\end{array}$ \\
\hline
\end{tabular}

Tabel 2. Tumbuhan tanpa literatur empiris

\begin{tabular}{|c|c|c|c|c|c|}
\hline No & Nama Tumbuhan Obat & $\begin{array}{c}\text { Bagian } \\
\text { Digunakan }\end{array}$ & $\begin{array}{l}\text { Khasiat } \\
\text { Empiris }\end{array}$ & $\begin{array}{c}\text { Cara } \\
\text { Pengolahan }\end{array}$ & Aturan Pakai \\
\hline $\mathrm{I}$. & 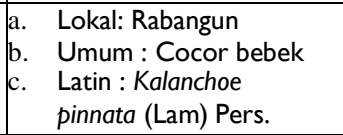 & Akar & $\begin{array}{l}\text { Sebagai } \\
\text { penyubur } \\
\text { kandungan }\end{array}$ & $\begin{array}{l}\text { Akar Rabangun direbus dengan air } \\
\text { hingga mendidih. }\end{array}$ & $\begin{array}{l}\text { Air rebusan akar Rabangun } \\
\text { diminum } 2 x \text { sehari I gelas. }\end{array}$ \\
\hline \multirow[t]{2}{*}{2.} & $\begin{array}{ll}\text { a. } & \text { Lokal : Sawangkak } \\
\text { b. } & \text { Umum : Pacing } \\
\text { c. } & \text { Latin : Costus } \\
& \text { specious (Koenig). }\end{array}$ & Batang & $\begin{array}{l}\text { Meredakan } \\
\text { batuk }\end{array}$ & $\begin{array}{l}\text { Batang tumbuhan Sawangkak } \\
\text { dipotong ujungnya, lalu kumpulkan } \\
\text { air tetesan yang keluar dari } \\
\text { batangnya dengan wadah gelas, } \\
\text { mulai dari sore hingga pagi hari. }\end{array}$ & $\begin{array}{l}\text { Air tetesan batang } \\
\text { Sawangkak diminum Ix } \\
\text { sehari, pada pagi hari. }\end{array}$ \\
\hline & & Bunga & $\begin{array}{l}\text { Mengobati } \\
\text { sakit gigi }\end{array}$ & $\begin{array}{l}\text { Bunga Sawangkak direbus dengan } \\
\text { air hingga mendidih. }\end{array}$ & $\begin{array}{l}\text { Air rebusan bunga } \\
\text { Sawangkak digunakan } \\
\text { untuk berkumur. }\end{array}$ \\
\hline 3. & 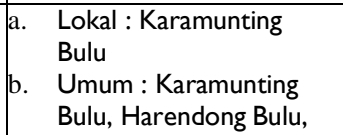 & Daun & $\begin{array}{l}\text { Mengobati } \\
\text { kencing manis }\end{array}$ & $\begin{array}{l}\text { Daun Karamunting Bulu direbus } \\
\text { dengan air hingga mendidih. }\end{array}$ & $\begin{array}{l}\text { Air rebusan daun } \\
\text { Karamunting Bulu } \\
\text { diminum } 2 x \text { sehari I } \\
\text { gelas. }\end{array}$ \\
\hline
\end{tabular}




\begin{tabular}{|c|c|c|c|c|c|}
\hline & \begin{tabular}{|l} 
Senduduk Bulu \\
c. \\
Latin : Clidemia hirta \\
(L)D.Don.
\end{tabular} & & & $\begin{array}{l}\text { Daun Karamunting Bulu } \\
\text { dikonsumsi langsung. }\end{array}$ & $\begin{array}{l}\text { Daun Karamunting Bulu } \\
\text { dikunyah } 2 x \text { sehari I } \\
\text { lembar daun. }\end{array}$ \\
\hline 4. & $\begin{array}{ll}\text { a. } & \text { Lokal : Kastela } \\
\text { b. } & \text { Umum : Pepaya } \\
\text { c. } & \text { Latin : Carica papaya } \\
& \text {.L. }\end{array}$ & Daun & $\begin{array}{l}\text { Mengobati } \\
\text { batu ginjal }\end{array}$ & $\begin{array}{l}\text { Daun Kastela direbus dengan air } \\
\text { hingga mendidih. }\end{array}$ & $\begin{array}{l}\text { Air rebusan daun Kastela } \\
\text { diminum } 2 x \text { sehari I gelas. }\end{array}$ \\
\hline 5. & \begin{tabular}{|ll} 
a. & Lokal : Mengkudu \\
b. & Umum : Mengkudu \\
c. & Latin : Morinda \\
& citrifolia L. \\
\end{tabular} & Daun & $\begin{array}{l}\text { Mengobati } \\
\text { stroke }\end{array}$ & $\begin{array}{l}\text { Daun Mengkudu dibakar hingga } \\
\text { layu. }\end{array}$ & $\begin{array}{l}\text { Daun Mengkudu yang telah } \\
\text { dibakar, ditempelkan pada } \\
\text { bagian tubuh yang } \\
\text { terkena stroke Ix sehari }\end{array}$ \\
\hline \multirow[t]{2}{*}{6.} & \multirow{2}{*}{\begin{tabular}{|ll} 
a. & Lokal : Gusar \\
b. & Umum: Gusar \\
c. & Latin: Dianela ensifolia \\
& (L.) DC.
\end{tabular}} & Akar & $\begin{array}{l}\text { Mengobati } \\
\text { asma }\end{array}$ & $\begin{array}{l}\text { Akar Gusar direbus dengan air } \\
\text { hingga mendidih. }\end{array}$ & $\begin{array}{l}\text { Air rebusan akar gusar } \\
\text { diminum } 2 x \text { sehari I gelas. }\end{array}$ \\
\hline & & Bunga & $\begin{array}{l}\text { Mengobati } \\
\text { jerawat }\end{array}$ & $\begin{array}{l}\text { Bunga Gusar dan beras ditumbuk } \\
\text { hingga halus. }\end{array}$ & $\begin{array}{l}\text { Bunga gusar dan beras } \\
\text { yang sudah halus, } \\
\text { dioleskan Ix sehari pada } \\
\text { bagian kulit yang } \\
\text { berjerawat. }\end{array}$ \\
\hline 7. & $\begin{array}{ll}\text { a. } & \text { Lokal : Tabuluh } \\
\text { b. } & \text { Umum : Tabuluh } \\
\text { c. } & \text { Latin : Pellacalyx } \\
& \text { axillaries Korth. }\end{array}$ & Daun & $\begin{array}{l}\text { Mengobati } \\
\text { kanker }\end{array}$ & $\begin{array}{l}\text { Daun Tabuluh direbus dengan air } \\
\text { hingga mendidih. }\end{array}$ & $\begin{array}{l}\text { Air rebusan daun } \\
\text { Tabuluh diminum } 2 x \\
\text { sehari I gelas. }\end{array}$ \\
\hline \multirow[t]{2}{*}{8.} & \multirow[t]{2}{*}{$\begin{array}{ll}\text { a. } & \text { Lokal : Urang Iru } \\
\text { b. } & \text { Umum : Daun Afrika } \\
\text { c. } & \text { Latin : Vernonia } \\
& \text { amygdalina Delile. }\end{array}$} & Daun & $\begin{array}{l}\text { Menurunka } \\
\mathrm{n} \text { tekanan } \\
\text { darah }\end{array}$ & $\begin{array}{l}\text { Daun Urang Iru direbus dengan } \\
\text { air hingga mendidih. }\end{array}$ & $\begin{array}{l}\text { Air rebusan daun Urang } \\
\text { Iru, diminum } 2 x \text { sehari I } \\
\text { gelas. }\end{array}$ \\
\hline & & Daun & $\begin{array}{l}\text { Mengobati } \\
\text { gatal pada } \\
\text { kulit }\end{array}$ & $\begin{array}{l}\text { Daun Urang Iru ditumbuk hingga } \\
\text { halus. }\end{array}$ & $\begin{array}{l}\text { Daun Urang Iru yang telah } \\
\text { ditumbuk, ditempelkan } \\
\text { pada bagian kulit yang } \\
\text { gatal. }\end{array}$ \\
\hline 9. & $\begin{array}{ll}\text { a. } & \text { Lokal :Kalamenyu } \\
\text { b. } & \text { Umum : Akar } \\
& \text { Kelimpar } \\
\text { c. } & \text { Latin : Embelia ribes }\end{array}$ & Akar & $\begin{array}{l}\text { Meredakan } \\
\text { asma }\end{array}$ & $\begin{array}{l}\text { Akar Kalamenyu ditumbuk } \\
\text { hingga halus, lalu peras airnya. }\end{array}$ & $\begin{array}{l}\text { Air perasan akar } \\
\text { Kalamenyu diminum } 2 x \\
\text { sehari. }\end{array}$ \\
\hline
\end{tabular}


Nurul Qamariah, Rezqi Handayani, Opi Indriani. 202I. Ethnopharmacology And Medicinal Plant Inventory In Kapuas Hilir District, Kapuas District, Central Kalimantan

Secara empiris tumbuhan Kumis Kucing digunakan sebagai obat Infeksi Saluran Kemih. Penelitian Reshi et al. (2017) Menyatakan bahwa ekstrak kalus yang berasal dari daun dan ekstrak daun Orthosiphon Aristatus (Blume) Miq, efektif dalam melawan pertumbuhan bakteri gram positif dan bakteri gram negatif. Ekstrak daun Kumis Kucing memiliki aktivitas antibakteri terhadap bakteri Staphylococcus aureus (Yulinati, 20I5), Salmonella thypi (Rukmana \& Mulyowati, 20I5), Peudomonas aeruginosa, dan aeromonas hydrophilla (Nair et al., 20I4). Infeksi yang terjadi pada saluran kemih dapat disebabkan oleh adanya infeksi bakteri sehingga kumis kucing dapat digunakan untuk mengobati infeksi tersebut.

Secara empiris tumbuhan Strobilanthes crispa BI. digunakan sebagai peluruh batu ginjal, hal ini didukung oleh penelitian Dharma et al. (20l4) Ekstrak etanol daun Strobilanthes crispa BI. memiliki daya melarutkan batu ginjal, semakin tinggi dosis ekstrak maka semakin besar jumlah komponen batu ginjal (kalsium dan oksalat) yang terlarut dalam urin. Sehingga tumbuhan Strobilanthes crispa $\mathrm{Bl}$. dapat digunakan sebagai obat peluruh batu ginjal.

Secara empiris tumbuhan Annona muricata .L digunakan untuk menurunkan tekanan darah, hal ini didukung oleh penelitian Sukandar et al. (2014) yang menyatakan bahwa ekstrak etanol daun Sirsak (Annona muricata .L.) dapat menghambat peningkatan tekanan darah sistol dengan menghambat reseptor adrenalin, serta penelitian Sangging et al. (2017) yang menyatakan bahwa senyawa yang terkandung dalam Annona muricata dapat berpengaruh secara signifikan terhadap penurunan tekanan darah.

Secara empiris tumbuhan Tabernaemontana divaricata (L) digunakan untuk mengobati bisul yang ada di dalam hidung, bisul dapat muncul akibat adanya infeksi bakteri, dalam Penelitian Baishya et al. (2018) menyatakan bahwa kulit batang Tabernaemontana divaricata (L) memiliki aktivitas antimikroba terhadap organisme patogen yang resisten terhadap berbagai obat, sehingga tumbuhan Tabernaemontana divaricata dapat digunakan untuk mengobati bisul didalam hidung yang disebabkan oleh infeksi bakteri.

Daun Kalanduyung (Guazuma ulmifolia Lamk.) secara empiris digunakan oleh masyarakat kapuas hilir sebagai obat batuk. Infeksi saluran pernafasan merupakan salah satu penyebab terjadinya batuk, salah satu infeksi saluran pernafasan yang dapat menyebabkan batuk yaitu Pneumonia (Trisia et al., 2018). Pneumonia merupakan infeksi akut pada parenkim paru, bronkiolus respiratorius dan alveoli, yang dapat disebabkan oleh bakteri Staphylococcus aureus. Berdasarkan penelitian Trisia et al. (2018) menyatakan bahwa ekstrak etanol daun Kalanduyung (Guazuma ulmifolia Lamk.) dapat menghambat pertumbuhan bakteri Staphylococcus aureus. Sehingga daun Kalanduyung bisa digunakan untuk mengobati batuk yang disebabkan oleh infeksi bakteri Staphylococcus aureus.

Secara empiris tumbuhan Tithonia diversifolia (hemsl) digunakan untuk menurunkan glukosa darah pada penderita diabetes melitus, hal ini didukung oleh penelitian Sari et al. (2018) yang menyatakan bahwa Tithonia diversifolia (hemsl) memiliki potensi sebagai penurun kadar glukosa darah, serta penelitian Sitanggang (2018) menyatakan bahwa Infusa daun Tithonia diversifolia (hemsl) dapat menurunkan kadar glukosa darah dan pada konsentrasi $60 \%$ sudah memberikan efek yang hampir sama atau mendekati efek Glibenklamid, sehingga tumbuhan Tithonia diversifolia (hemsl) dapat digunakan sebagai penurun kadar glokusa darah.

Secara empiris Cassia alata (L) Roxb digunakan sebagai penurun kadar kolestrol dan mengobati panu, hal ini didukung oleh penelitian Depita (2018) yang menyatakan bahwa ekstrak etanol daun ketepeng cina (Cassia alata (L) Roxb) memiliki efek antihiperlipidemia yang dimana dapat menurukan kadar kolesterol, serta penelitian Triana et al. (20l6) menyatakan bahwa 
ekstrak daun ketepeng cina (Cassia alata (L) Roxb.) memiliki aktivitas antijamur terhadap jamur Malassezia furfur yang merupakan jamur penyebab panu. Berdasarkan khasiat farmakologisnya maka Cassia alata (L) Roxb dapat digunakan sebagai penurun kadar kolestrol dan pengobatan panu.

Secara empiris tumbuhan Paspalum conjugatum (Berg.) digunakan untuk mengobati luka luar dan luka dalam tubuh. Luka ialah kerusakan pada struktur anatomi kulit yang menyebabkan terjadinya gangguan pada kulit, luka dapat mengakibatkan infeksi jika telah terkontaminasi oleh debu atau bakteri yang disebabkan karena luka tidak dirawat dengan baik. Staphylocus aureus adalah bakteri yang dapat menyebabkan infeksi pada kulit yang terdapat luka (Sim \& Romi, 2009). Menurut Muswanto (2019), Ekstrak etanol daun Paspalum conjugatum (Berg.) memiliki aktivitas sebagai antibakteri yang relatif tinggi terhadap bakteri Staphylococus aureus, sehingga Paspalum conjugatum (Berg.) dapat digunakan untuk mengobati luka dan mencegah terjadinya infeksi pada luka tersebut.

Secara empiris tanaman Curcumae zeddoariae digunakan untuk mengobati bisul, belum ditemukan penelitian yang menyatakan bahwa Curcmae zeddoariae dapat digunakan untuk mengobati bisul namun berdasarkan pada Penelitian Busman et al. (2019) menyatakan bahwa ekstrak rimpang Curcuma zedoariae dapat menghambat pertumbuhan bakteri Streptococcus mutans dan bakteri Staphylococcus aureus. Penelitian Primawati et al. (20I3) menunjukkan bahwa kurkumin yang terdapat dalam ekstrak metanol kunyit putih dapat meningkatkan proliferasi leukosit, dengan pemberian ekstrak metanol Curcumae zeddoariae sebagai imunomodulator dapat menjaga kestabilan sistem imunitas tubuh mencit meskipun diberikan infeksi, serta Menurut Lai et al. (2004) minyak atsiri dari Curcumae zeddoariae memiliki aktivitas antimikroba terhadap bakteri gram positif dan gram negatif. Melihat adanya aktivitas antibakteri yang baik dari tumbuhan Curcumae zeddoariae sehingga tumbuhan ini dapat berpotensi untuk mengobati bisul. Secara Empiris Tanaman Ludwigia decurrens Walter digunakan untuk mengobati bisul, belum ditemukan penelitian yang menyatakan bahwa Ludwigia decurrens dapat digunakan untuk mengobati bisul namun pada Penelitian Oyedeji et al. (20II) menyatakan bahwa Ludwigia decurrens Walter memiliki aktivitas antibakteri yang baik dan efektif digunakan dalam berbagai pengobatan penyakit infeksi. Aktivitas antibakteri dari tumbuhan Ludwigia decurrens Walter dapat berpotensi untuk mengobati bisul yang disebabkan oleh infeksi bakteri.

Secara empiris bagian batang Tinospora crispa (L.) miers digunakan sebagai penghilang sakit pinggang hal ini didukung oleh penelitian Septian et al. (2016) yang menyatakan bahwa infusa dari batang brotowali (Tinospora crispa (L.) miers) mempunyai efek analgetik, sehingga Tinospora crispa (L.) miers dapat digunakan sebagai penghilang nyeri atau sakit pada pinggang. Secara empiris Artocarpus altilis digunakan sebagai penurun kadar kolesterol darah hal ini didukung oleh penelitian Tandi et al. (2017) yang menyatakan bahwa ekstrak etanol daun sukun (Artocarpus altilis) memiliki efek dalam menurunkan kadar glukosa darah, dan kadar kolesterol darah. Secara empiris Drynaria quercifolia (L) J. Sm digunakan sebagai obat kanker, hal ini didukung oleh penelitian Prasanna et al. (2019) yang menyatakan bahwa ekstrak Drynaria quercifolia (L) J. memiliki efek sitotoksik dan berpotensi untuk mengobati kanker hati.

\section{KESIMPULAN}

Berdasarkan hasil penelitian tentang penggunaan tumbuhan berkhasiat obat oleh masyarakat Suku Dayak di Kecamatan Kapuas Hilir Kabupaten Kapuas Kalimantan Tengah, dapat disimpulkan sebagai berikut:

I. Terdapat 22 jenis tumbuhan berkhasiat obat yang dimanfaatkan yaitu Rabangun, Kumis Kucing, Keji 
Beling, Sawangkak, Karamunting Bulu, Kastela, Sirsak, Mengkudu, Katatuak, Gusar, Kalanduyung, Tabuluh, Insulin, Gelinggang, Urang Iru, Uru Balanda, Henda Baputi, Uru Samue, Panawar Gantung, Sukun, Pahakung, dan Kalamenyu.

2 Bagian tumbuhan berkhasiat obat yang digunakan adalah kulit batang, rimpang, herba, bunga, batang, akar dan yang paling banyak adalah bagian daun.

3. Cara pengolahan tumbuhan berkhasiat obat adalah dengan cara direndam air hangat, dibakar, dibuat kapsul, dikonsumsi langsung, ditumbuk dan yang paling sering adalah diolah dengan cara direbus.

4. Khasiat empiris dari tumbuhan berkhasiat obat yang digunakan sebagian besar masih belum didukung oleh data hasil penelitian.

\section{UCAPAN TERIMA KASIH}

Ucapan terima kasih kepada seluruh sivitas akademika yang telah membantu dalam proses Penelitian. Enumerator Penelitian yang meluangkan waktu dalam pengumpulan data. Instansi Rumah sakit sebagai tempat penelitian yang telah memberikan kesempatan.

\section{REFERENSI}

I. Sintha, D. 2012. Kajian Etnofarmakologi Makasar Dari Beberapa Tanaman yang Digunakan Untuk Mengobati Penyakit Hipertensi. Skripsi. Universitas Hasanudin. Makassar.

2. Mirdeilami, S. Z., Hossein, B., Masumeh, M. \& Gholam, A. H. 20II. Etnopharmacological Survey Of Medical Plant In Maraveh Tapeh Region, North of Irian. Irianian Journal of Plant Physiologi Vol. 2 (I).

3. Pitoyo, A. \& Triwahyudi, H. 2017. Dinamika Perkembangan Etnis di Indonesia Dalam Persatuan Negara. Jurnal Populasi Vol.25 (I): 64-8I.

4. Sugiyono. 2010. Metode Penelitian Administratif. Alfabeta: Bandung.

5. Steenis, V. 2005. Flora untuk Sekolah di Indonesia. Pradnya Paramita: Jakarta.
6. Reshi, N. A., Sudarshana, M.S. \& Girish, V.H. 2017. Evaluation of Antibacterial Potential Of Leaf And Leaf Derived Callus Extracts Of Orthosiphon Aristatus (Blume) Miq. Asian Journal of Pharmaceutical and Clinical Research Vol I0(5): 245249.

7. Dharma, S., Aria, M. \& Syukri, E. F. 2014. Pengaruh Ekstrak Etanol Daun Kejibeling (Strobilanthes Crispa (L) Blume) Terhadap Kelarutan Kalsium Dan Oksalat Sebagai Komponen Batu Ginjal Pada Urin Tikus Putih Jantan. Scientia Vol. 4(I): 34-37.

8. Sukandar, E. Y., Sigit, J. I. \& Dewi, N. P. 20I4. Uji Efek Penurunan Tekanan Darah Ekstrak Etanol Daun Sirsak (Annona muricata L.) pada Tikus Wistar Jantan. Acta Pharmaceutica Indonesia Vol. 39 (I\&2): $4 \mid-44$.

9. Sangging, P. R. A. \& Sari, M. R. N. 2017. Efektivitas Teh Daun Sirsak (Annona muricata Linn) terhadap Hipertensi. Majority Vol 6(2): 49-54.

10. Baishya, M. K., Saikia, K. K., Hazarika, N. K., Baishya, D. \& Das, D. J. 2018. Antimicrobial Potential and In Vitro Cytotoxicity study of Tabernaemontana divaricata (L.) Stem Bark Extract Against HEK 293 Cell Line. IOSR Journal Of Pharmacy Vol. 8(3): I I-I8.

II. Trisia, A., Philyria, R. \& Toemon, A. N. 2018. Uji Aktivitas Antibakteri Ekstrak Etanol Daun Kalanduyung (Guazuma ulmifolia Lam.) Terhadap Pertumbuhan Staphylococcus Aureus Dengan Metode Difusi Cakram (Kirby- Bauer). Anterior Jurnal Vol I7(2): I36-143.

12. Sari, A. R., Saraswati, T. R. \& Yuniwarti, E.Y. W. 2018. Antihyperglycemic Activity of Aqueous Extract of Insulin Leaves (Tithonia diversifolia) on Hyperglycemic Rats (Rattus norvegicus). Journal of Biology \& Biology Education Vol. 10(3): 636-64.

13. Depita, S. C. 2018. Uji Aktivitas Antihiperlipidemia Ekstrak Etanol Daun Ketepeng Cina (Senna alata) Terhadap Tikus Putih Jantan Galur Wistar Yang Diinduksi Propiltiourasil. Skripsi. Universitas Sriwijaya, Inderalaya.

14. Triana, O., Fajar, P., Hadi, K. \& Laode, R. 2016. Aktivitas Antijamur Ekstrak Daun Ketepeng Cina ( Cassia alata L.). Jurnal Sains dan Kesehatan Vol. I(6): 3II-3|5. 
15. Muswanto, E. 2019. Uji Aktivitas Antibakteri Ekstrak Etanol Daun Jukut Pahit (Paspalum conjugatum) Asal Desa Pongruan Kabupaten Manggarai Timur Terhadap Bakteri Staphylococcus Aureus dan Kajian Senyawa Aktif. Skripsi. Universitas Katolik Widya Mandira, Kupang.

16. Lai, E. Y. C., Chyau, C. C., Mau, J. L., Chen, C. C., Lai, Y. L., Shih, C. F. \& Lin, L.L. 2004. Antimicrobial Activity and Cytotoxicity of the Essential Oil of Curcuma zedoaria. The American Journal of Chinese Medicine Vol. 32 (2): 28I-290.

17. Oyedeji, O., Oziegbe, M., \& Taiwo, F. O. 2014. Antibacterial, antifungal and phytochemical analysis of crude extracts from the leaves of Ludwigia abyssinica A. Rich. and Ludwigia decurrens Walter. Journal of Medicinal Plants Research Vol. 5(7): II921199

18. Septian, P. C. 2016. Uji Efek Analgetik Infusa Batang Brotowali (Tinospora Crispa (L.) Miers) Pada Mencit Putih Jantan Galur Swiss (Mus Musculus). Skripsi. Universitas Muhammadiyah Surakarta, Surakarta.

19. Tandi, J., Rizky, M., Mariani, R. \& Alan, F. 2017. Uji Efek Ekstrak Etanol Daun Sukun (Artocarpus altilis (Parkinson Ex F.A.Zorn) Terhadap Penurunan Kadar Glukosa Darah, Kolesterol Total dan Gambaran Histopatologi Pankreas Tikus Putih Jantan (Rattus norvegicus) Hiperkolesterolemiadiabetes. Jurnal Sains dan Kesehatan Vol. I(8): 384396.

20. Prasanna, G., Devi, R. \& Ishwarya, G. 2019. In Vitro Evaluation Of Antidiabetic And Cytotoxicity Potentials Of The Rhizome Extract Of Drynaria Quercifolia (L.) J. Smith. Asian Journal Pharmaceutical and Clinical Research, Vol. I2(I I): 72-76.

21. Yulianti, R., Nugraha, D. A. \& Nurdianti, L. 2015. Formulasi Sediaan Sabun Mandi Cair Ekstrak Daun Kumis Kucing (Orthosiphon aristatus (BI) Miq). Kartika-Jurnal IImiah Farmasi Vol 3(2): I-I

22. Rukmana, R. M. \& Mulyowati, T. 2015. Aktivitas Antibakteri dari Ekstrak Etanolik Daun Kumis Kucing (Orthosiphon stamineus) pada Bakteri Streptococcus pyogenes dan Salmonella thypi. Biomedika Vol 6 (2): I6-18.

23. Nair. A., Kirutika. D., Dheeba. B. \& Tilton. F. $20 \mid 4$. Cytotoxic Potential Of Orthosiphon stamineus Leaf Extracts Again Pathogenic bacteria And Colon Cancer Cells. Asian Journal Of Science and Technology Vol. 5(3): 221-225.
24. Sim \& Romi. 2009. Kejadian Infeksi Luka Episitomi dan Pola Bakteri pada Persalinan Normal di RSUD H. Adam Malik dan RSUD dr. Pimgadi Medan. Tesis. Universitas Sumatera Utara, Medan.

25. Busman., Edrizal \& Wirahmi, S. D. 2019. Daya Hambat Ekstrak Rimpang Temu Putih (Curcuma zedoaria) Terhadap Streptococcus mutans dan Staphylococcus aureus. Menara IImu Vol. I(6): 20-28.

26. Primawati, S. N., Dwi, S. D. J. \& Zulkifli, L. 2013. Profil Kualitatif Komponen Ekstrak Kunyit Putih (Curcuma zedoaria) dan Pengaruhnya Terhadap Profil Hematologi Mencit yang di Infeksi Salmonella typhimurium. Jurnal Biologi Tropis Vol. I3(2): I39- 145. 
